\title{
THE LOST GARDEN
}

\section{A View of Shakespeare's English and Roman}

History Plays 
Edited by John Wilders

Samuel Butler: Hudibras, with an Introduction and Commentary (1967)

Shakespeare: The Merchant of Venice (Casebook series) (1969) 


\section{THE LOST GARDEN}

A View of Shakespeare's English and Roman History Plays

\section{JOHN WILDERS}




\section{John Wilders 1978}

Softcover reprint of the hardcover 1st edition 1978

All rights reserved. No part of this publication may be reproduced or transmitted, in any form or by any means, without permission.

First published 1978 by

THE MACMILLAN PRESS LTD

London and Basingstoke

Associated companies in Delhi Dublin

Hong Kong Johannesburg Lagos Melbourne

New York Singapore and Tokyo

\section{British Library Cataloguing in Publication Data}

Wilders, John

The lost garden.

1. Shakespeare, William-Histories

I. Title

$822.3^{\prime} 3$

PR 2982

ISBN 978-0-333-24470-8 ISBN 978-1-349-15951-2 (eBook)

DOI 10.1007/978-1-349-15951-2

This book is sold subject to the standard conditions of the Net Book Agreement.

The paperback edition of this book is sold subject to the condition that it shall not, by way of trade or otherwise, be lent, resold, hired out, or otherwise circulated without the publisher's prior consent in any form of binding or cover other than that in which it is published and without a similar condition including this condition being imposed on the subsequent purchaser. 


\section{Contents}

Foreword $\quad$ ix

Note on References $\quad$ xi

1 History and Tragedy 1

2 Time and Change 11

3 Fortune and Nature 29

4 Prayer, Prophecy and Providence 53

5 Knowledge and Judgement 79

6 Dilemma and Discovery 102

7 The Lost Garden 125

$\begin{array}{ll}\text { Notes and References } & 144\end{array}$

Index 153

The cover illustration, adapted from a fifteenth-century frontispiece to a manuscript of John Lydgate's The Fall of Princes, is reproduced by permission of the Curators of the Bodleian Library, Oxford. It depicts the expulsion of Adam and Eve from the Garden of Eden and the falls from power of various historical figures. 
For Catherine 1956-1975 
It was, after all, the Greeks who pioneered the writing of history as what it has so largely remained, an exercise in political ironics - an intelligible story of how men's action produces results other than intended.

\author{
J.G. A. Pocock
}

Comfort's in heaven; and we are on the earth.

Richard II, II ii 78 


\section{Foreword}

Every time Shakespeare wrote a play he set for himself a new kind of challenge with the result that each one is unique in style, construction, characterisation and dramatic effect. Not the least achievement of the history plays is their diversity. The uniqueness of each history play is, however, not my concern in this book, nor have I paid much attention to Shakespeare's development as a poet and dramatist. What I have tried to convey is my belief, based on my acquaintance with the plays as a reader, actor, theatregoer and teacher, that the mind which created all the history plays was guided by certain largely unchanging assumptions. Whether Shakespeare is portraying the struggle between the Greeks and Trojans, the conspiracy against Julius Caesar or the victory of Henry V at Agincourt, his imagination is, I believe, governed by a view of human nature which he held irrespective of the historical period he chose to depict. Shakespeare's view of human nature shaped his view of history and it is these two interrelated attitudes which I have tried to describe and illustrate in the following chapters.

His view of human nature appears as evidently in his tragedies and comedies as in his histories, and the contents of this book could well have been only part of a much larger work dealing with the entire canon. I have confined myself to the histories partly because I was unwilling to embark on a larger enterprise and partly because these plays seemed to me in need of a fresh appraisal. Interpretation of the English histories has been and still is very strongly influenced by E. M. W. Tillyard's Shakespeare's History Plays (1944), even though it was published over thirty years ago and in spite of the challenges it has received from Wilbur Sanders, Robert Ornstein, H. A. Kelly and others. Tillyard's account of these plays can be found not only in his own writings but in such influential places as the standard editions of 
Shakespeare, discussions of his historical sources and many otherwise admirable works of criticism. I believe, however, that Tillyard seriously misinterpreted the plays and oversimplified the opinions of the chroniclers. Even if readers are unconvinced by my own arguments, I hope they may be encouraged to think again about assumptions which have long been widely accepted.

The effect of Tillyard's book has also been to separate the English histories from the rest of Shakespeare's work by creating the impression that, in writing them, he ceased for the time being to engage in the free-ranging speculations he conducted elsewhere in order to assume a much more rigid, official position, a 'Tudor' view of history which has no connection with the attitudes implicit in the tragedies and Roman plays. One of my purposes has been to establish the connections between the English and Roman histories and their connections with the tragedies, and thereby to restore the English histories to their place in Shakespeare's writings as a whole.

As each of the following chapters took shape I was reassured to discover that Shakespeare's ideas were often similar to those of his predecessors and contemporaries. I am not thinking of the chroniclers but of more profoundly influential writers such as St Augustine, Boethius, Calvin, Machiavelli and Montaigne. My treatment of Shakespeare could well have been prefaced by an account of his philosophical and theological 'background', but I have preferred to allude to these authors only occasionally when their ideas seemed to me relevant and to offer some explanation why the dramatist thought as he did. Any reader who is curious to trace Shakespeare's ideas to their sources should consult Hiram Haydn's The Counter-Renaissance (New York, 1950) which describes an 'Elizabethan World Picture' very different from Tillyard's, in which Shakespeare's intellectual predecessors are shown to have been sceptical and uncertain, conscious of their ignorance of God and man, living in a universe characterised not by its stability and order but by its innate tendency towards chaos.

My best teachers have been my pupils and I am indebted to the students at the universities of Princeton, Bristol, Oxford and California for their insights and the good-natured challenges they have given me. I have acknowledged my debts to the scholars and critics of whose ideas I have consciously made use, but no doubt I have failed to mention others who have influenced me in ways I can no longer recall. To those who find their ideas repeated here without acknowledgement, I offer my apologies and gratitude. 
This book would probably not have been written had it not been for the generosity of my colleagues at Worcester College, Oxford, in allowing me a year's leave, and of the Australian National University in awarding me a Visiting Fellowship at their Humanities Research Centre where I was able to work without interruption and in very favourable conditions. I am particularly grateful to the Director of the Centre, Professor Ian Donaldson, and to Professor S. L. Goldberg of the History of Ideas Unit for their criticism and encouragement. I am also indebted to Dr Christopher Hill, the Master of Balliol, for helping me to place Shakespeare in his religious and philosophical context. If this book is intelligible it is largely because it has passed through the critical scrutiny of my wife who, with characteristic modesty, claims that if she can understand my prose, it must be intelligible to anyone.

The book is dedicated to the memory of our daughter Catherine who, had she lived, would have been a university student of English literature at the time I wrote it.

JOHN WILDERS

Note on References

References to Shakespeare's text are to Peter Alexander's edition of The Complete Works (London and Glasgow: Collins, 1951). 